Schofield, L. N., H. L. Loffland, R. B. Siegel, C. Stermer, and H. A. Mathewson. 2018. Using conspecific broadcast for Willow Flycatcher restoration. Avian Conservation and Ecology 13(1):23. https://doi.org/10.5751/ACE-01216-130123

Copyright $(C) 2018$ by the author(s). Published here under license by the Resilience Alliance.

Research Paper

\title{
Using conspecific broadcast for Willow Flycatcher restoration
}

Lynn N. Schofield ${ }^{1}$, Helen L. Loffland ${ }^{1}$, Rodney B. Siegel ${ }^{1}$, Chris J. Stermer ${ }^{2}$ and Heather A. Mathewson ${ }^{3}$

${ }^{1}$ The Institute for Bird Populations, ${ }^{2}$ California Department of Fish and Wildlife, ${ }^{3}$ Department of Wildlife, Sustainability, and Ecosystem Sciences, Tarleton State University

\begin{abstract}
Willow Flycatcher (Empidonax traillii) populations have been in decline across the western United States for decades. California populations are especially vulnerable with fewer than 500 pairs remaining in the state. Declines and local extirpations continue despite extensive habitat restoration and improved management designed to help conserve Willow Flycatchers. Such efforts may have failed to help reverse these trends in part because Willow Flycatchers rarely recolonize habitat after extirpation, regardless of present habitat suitability. Failure to recolonize habitat may be because prospecting Willow Flycatchers, like many other songbird species, assess habitat suitability based on the presence of conspecifics, making them unlikely to consider unoccupied habitat as potential breeding grounds. If true, broadcasting conspecific vocalizations in suitable but unoccupied habitat could help facilitate recolonization. During the 2016 and 2017 breeding seasons, we assessed the effectiveness of providing artificial social cues as a means of restoring Willow Flycatchers to suitable but unoccupied restored meadows in the Sierra Nevada mountains of California. We selected 14 experimental meadows where conspecific songs were broadcast during the settlement and breeding periods and 19 control meadows where no broadcasts took place. All the meadows were recently restored, contain high-quality habitat with hydrological characteristics and vegetation similar to meadows where Sierra Willow Flycatchers successfully breed, and were confirmed to be unoccupied in the year prior to their inclusion in the study. We observed Willow Flycatchers at five of 14 experimental meadows (35.75\%) during the breeding season and at one of 19 control meadows (5.3\%). We found that habitat characteristics also play a role in the efficacy of this technique, as Willow Flycatcher presence was highly significantly related to the combination of both the experimental treatment and meadow size. These results demonstrate that within large, restored meadows, conspecific broadcasts may be an effective strategy for restoring Willow Flycatchers.
\end{abstract}

\section{Utilisation de la diffusion de chants de conspécifiques pour le rétablissement du Moucherolle des saules}

RÉSUMÉ. Les populations de Moucherolles des saules (Empidonax traillii) sont à la baisse dans tout l'ouest des États-Unis depuis des décennies. Les populations californiennes sont particulièrement vulnérables, comptant moins de 500 couples. Les baisses et les disparitions locales se produisent toujours malgré les efforts importants de restauration d'habitat et d'aménagement ciblant la conservation de ces moucherolles. Ces efforts pourraient avoir failli à renverser les tendances, en partie en raison du fait que le Moucherolle des saules recolonise rarement un habitat qu'il a abandonné, sans égard aux conditions actuelles propices. L'échec de la recolonisation d'habitat est peut-être attribuable au fait que les moucherolles qui prospectent, tout comme de nombreuses autres espèces d'oiseaux chanteurs, évaluent le caractère adéquat d'un habitat sur la base de la présence d'autres conspécifiques, ce qui les rend peu aptes à considérer un habitat inoccupé comme site potentiel de nidification. Si ceci s'avère juste, la diffusion de chants de conspécifiques dans des habitats inoccupés mais propices pourrait contribuer à faciliter la recolonisation par cette espèce. Durant les saisons de nidification 2016 et 2017, nous avons évalué l'efficacité de la diffusion de sons sociaux artificiels comme moyen d'attirer de nouveau des Moucherolles des saules dans des prairies restaurées inoccupées mais propices dans la Sierra Nevada de la Californie. Nous avons sélectionné 14 prairies expérimentales dans lesquelles nous avons diffusé des chants de conspécifiques au cours de l'établissement et de la saison de nidification et 19 prairies contrôles sans diffusion de chants. Toutes les prairies avaient été récemment restaurées, offraient de l'habitat de grande qualité, dont des caractéristiques hydrologiques et de la végétation similaires aux prairies dans lesquelles des Moucherolles des saules de la Sierra avaient auparavant niché avec succès, et étaient inoccupées l'année précédant leur inclusion dans la présente étude. Nous avons observé l'espèce dans 5 des 14 prairies expérimentales $(35,75 \%)$ durant la saison de nidification et dans 1 des 19 prairies contrôles $(5,3 \%)$. Nous avons constaté que les caractéristiques d'habitat jouaient aussi un rôle dans l'efficacité de cette technique, puisque la présence des moucherolles était très fortement liée à la combinaison du traitement expérimental et de la taille des prairies. Nos résultats indiquent que dans les vastes prairies restaurées, la diffusion de chants de conspécifiques pourrait être une stratégie efficace pour y attirer de nouveau les Moucherolles des saules.

Key Words: colonization; conservation; conspecific attraction; Empidonax traillii; habitat selection; social cues 


\section{INTRODUCTION}

The Willow Flycatcher (Empidonax traillii) is a widespread, riparian songbird that breeds throughout North America (Sedgwick 2000). Although common in some parts of its range, the species is rapidly declining across the western U.S. and is listed as endangered under the U.S. Endangered Species Act in the southwestern portion of its range (Mathewson et al. 2013, Beatty 2014, Loffland et al. 2014). The steepest declines are currently observed in California, where fewer than 500 pairs remain (Beatty 2014, Loffland et al. 2014).

Although considered to be the most numerous and widespread flycatcher species in California during the early 1900s, the Willow Flycatcher's range in the state has contracted dramatically and numbers have continued to decline since formal censuses began in the 1970s (Grinnell and Miller 1945, Harris et al. 1986, 1987, Small 1994, Bombay et al. 2003a, Mathewson et al. 2013, Loffland et al. 2014). Historic declines are primarily attributed to habitat loss and degradation of the breeding grounds caused by human use and development, especially intensive livestock grazing and altered hydrology (Harris et al. 1986, Valentine et al. 1988, Siegel et al. 2008, Mathewson et al. 2013).

In recent decades, however, grazing pressure has been reduced significantly, and numerous large-scale wetland restoration projects designed in part to improve habitat for riparian birds have been implemented across California (Pope et al. 2015, Oles et al. 2017). Despite apparently improving habitat conditions, Willow Flycatchers have not returned to restored habitat from which they have been lost, even when high-quality restored habitat is within the dispersal distance of potential source populations (Campos et al. 2014). Declines continue even as productivity and survival appear stable within those areas that remain occupied and despite apparently high overwinter survival for Willow Flycatchers overall (Mathewson et al. 2013, Paxton et al. 2017). Why Willow Flycatchers so rarely recolonize newly restored, high-quality habitat remains unknown but there is some indication that behavioral constraints may play a role.

Some territorial passerine species are known to rely on social cues such as the presence of conspecifics' songs to assess the quality of possible breeding habitat and are reluctant to establish territories where conspecifics are not present (Muller et al. 1997, Ward and Schlossberg 2004, Andrews et al. 2015). For many species, especially those with short breeding seasons, the presence of other members of their species might be used as an indirect way for naïve individuals to infer habitat quality and quickly find a suitable territory without investing substantial time (Hahn and Silverman 2006). Settling near conspecifics also may also help improve birds' fitness by providing opportunities for extra-pair mating and occasionally permitting polygyny (Ahlering et al. 2010).

Much like other songbirds with a tendency for conspecific attraction, Willow Flycatchers in California have exceptionally short breeding seasons, lasting less than three months (Sedgwick 2000); Willow Flycatcher territories are often clustered within larger habitat patches (Walkinshaw 1966); and polygyny is observed when population densities are sufficiently high (Prescott 1986, Hahn and Silverman 2006, Mathewson et al. 2013, Kus et al. 2017). For these reasons, providing social cues at restored habitat not yet occupied by flycatchers might be an effective means of encouraging prospecting individuals to establish territories in newly available habitat.

In this study we investigate whether broadcasting conspecific songs can attract Willow Flycatchers to vacant but suitable habitat that has recently been improved through hydrologic restoration and/or a cessation of livestock grazing. If conspecific broadcasts in suitable habitat can help to improve the colonization rates of Willow Flycatchers, the technique would provide a valuable tool for the species' conservation and recovery. We focus on a particular population of Willow Flycatchers (hereafter Sierra Willow Flycatcher) confined to the Sierra Nevada and the southernmost portion of the Cascade Range in California, for which restoration and conservation efforts have been notably unsuccessful at reversing population declines. The Sierra Willow Flycatcher is an ecologically distinct group that includes individuals from both the $E$. $t$. adastus and $E$. $t$. brewsteri subspecies and potential hybrids, and, unlike other populations of Willow Flycatcher, is almost completely reliant on midelevation wet meadows for breeding habitat (Harris et al. 1987, Sanders and Flett 1989, Bombay et al. 2003a, Mathewson et al. 2013). The Sierra Willow Flycatcher is currently confined to fewer than 70 wet meadows, only 11 of which support more than 10 pairs (H. Loffland, unpublished data), which makes it especially vulnerable to stochastic events and makes establishing populations in new or improved habitat extremely important. We also assess whether other factors, including moisture, vegetation cover, and meadow size, affect the efficacy of conspecific broadcast in facilitating colonization.

\section{METHODS}

\section{Study areas}

We selected 14 experimental meadows and 19 control meadows with suitable habitat for Sierra Nevada Willow Flycatchers on U. S. National Forest lands. Study meadows were dispersed across the Sierra Nevada and ranged from $38.06^{\circ}$ to $40.17^{\circ}$ latitude and 1500 to 2600 meters elevation. We considered meadows to be suitable habitat if they had vegetation and hydrological characteristics similar to meadows where Sierra Willow Flycatchers successfully breed (Bombay et al. 2003a). Within the Sierra Nevada and elsewhere in the montane west, dense willow cover is one of the best indicators of habitat quality at all spatial scales (Sedgwick and Knopf 1992, Bombay et al. 2003a, Vormwald et al.2011); therefore we selected study sites with stands of mature willow large enough to support multiple flycatcher territories ( 0.75 ha or more; Bombay 1999). Meadows that are consistently used for breeding by Willow Flycatchers in the region also have a pronounced wetland component and maintain standing or slow-moving surface water, or saturated soils, throughout most of the growing season. Therefore suitable study sites contained features such as oxbows, beaver ponds, springs, or other seasonal depressions within proximity of willow stands that retained water throughout most of the summer. We assessed habitat conditions at each meadow through pre-experiment survey visits, survey forms, and descriptions provided by partners, and visual inspection of 2012 National Agriculture Imagery Program (NAIP) imagery using ArcMap 10. 3 (Environmental Systems Research Institute, Redlands, CA) 
In addition to being suitable habitat overall, all meadows included in this study met four additional criteria: (1) they were surveyed with standardized broadcast surveys for Willow Flycatchers (Bombay et al. 2003b) in 2015 and/or 2016 and found to be unoccupied the year prior to inclusion in the experiment; (2) they were within the species' mean observed dispersal distance plus one standard deviation (12 km; Loffland et al. 2014) of meadows currently occupied by territorial Willow Flycatchers; (3) they have been restored or have had habitat quality improved by management practices; and (4) they were $<2 \mathrm{~km}$ from historically known breeding Willow Flycatcher breeding sites, and in many cases were known to have supported breeding Willow Flycatchers. Habitat restoration and improvement actions at study sites included active hydrological restoration such as channel filling or "pond-and-plug," or management actions that eliminated stressors that may have originally contributed to flycatcher extirpation, such as excessive livestock grazing (Hammersmark et al. 2008, Campos et al. 2014).

All meadows used in this experiment were surveyed for Willow Flycatchers the year(s) prior to their inclusion as a study site by The Institute for Bird Populations, the USDA Forest Service, or Point Blue Conservation Science, using Bombay et al. (2003b) to confirm flycatcher absence. Because of a limited number of meadows available that met the criteria for this study and were readily accessible and anticipated to be free of snow beginning in May 2017, we reused three uncolonized control meadows from 2016 as control meadows in 2017, and we used a fourth uncolonized control meadow from 2016 as an experimental meadow in 2017. To avoid biasing our results by selecting more or less suitable experimental or control sites, we randomly assigned the selected study meadows to experiment or control groups, except for four meadows where we had to accommodate land managers who did not want broadcast equipment installed, or where meadow access was too challenging to allow maintenance of broadcast equipment.

\section{Automated broadcasts}

The conspecific attraction experiment took place throughout the settlement and nesting period (approximately 15 May-25 July) of 2016 and 2017 following experimental protocols based on a pilot study conducted by Mathewson in 2007 (Mathewson et al. 2011). At each experimental meadow, we installed two automated broadcast systems programmed to play prerecorded Willow Flycatcher vocalizations at regular intervals interspersed with the songs and other vocalizations of bird species commonly heard within Sierra Nevada meadows (Dark-eyed Junco [Junco hyemalis], Song Sparrow [Melospiza melodia], and Lincoln's Sparrow [Melospiza lincolnii]), and periods of silence. We broadcast Willow Flycatcher vocalizations used by both males and females and to elicit reactions from both sexes, including the typical "fitz-bew" territorial song and "whitt" contact calls. We did not include any vocalizations that were typical of aggressive interactions between flycatchers. Similar to other studies of conspecific attraction, no broadcasts were used at control sites (Ward and Schlossberg 2004).

Broadcast intervals were between 01:00 and 05:00, 07:00-09:00, and 20:00-21:00 each day. These times were selected to coincide with peak territorial activity in the morning and evening, and with likely arrival because Willow Flycatchers are nocturnal migrants.
We changed batteries every 10-15 days to ensure that broadcasts continued uninterrupted throughout the deployment period. Broadcasts repeated a 10-minute loop consisting of a two minutes of "fitz-bew" and "whit" Willow Flycatcher vocalizations taken from a single individual who was vocalizing continuously while being recorded, two minutes of heterospecific songs, two minutes of "fitz-bew" and "whitt" Willow Flycatcher vocalizations taken from a second individual, two minutes of heterospecific songs, and two final minutes of silence. The recordings were obtained from Cornell's Macaulay Library, and were made in the Sierra Nevada region.

We initiated automated broadcast systems at each experimental meadow between 13 May and 31 May (Table 1), with the exception of one site in 2016 that did not become accessible until 18 June because of road conditions. Broadcasts continued throughout the nesting season until the final visit to each study site was completed in mid-July. The effect of ongoing broadcasts on nesting in potential colonists was assumed to be negligible, because passerines (including the closely related Alder Flycatcher [Empidonax alnorum]), have been shown to be minimally responsive to the songs of familiar neighbors once territories are established (Lovell and Lein 2004). We installed broadcast systems at least $200 \mathrm{~m}$ apart from one another within what field crew members qualitatively assessed as the most appropriate nesting habitat within a meadow, based on soil moisture or inundation, plant species composition, and vegetation structure. We did not place broadcast units within control meadows. Broadcast units consisted of a FOXPRO wildlife caller (FOXPRO, Lewiston, PA, USA) connected to a timer and an external power source (12 volt $35 \mathrm{AH}$ battery).

\section{Willow Flycatcher surveys}

Between 1 June and 15 July of 2015, 2016, and 2017, we conducted Willow Flycatcher surveys (Bombay et al. 2003b) at potential and current study sites to determine Willow Flycatcher presence or absence. We surveyed meadows twice during the year prior to inclusion in the study, to confirm absence. Two visits are routinely used to determine breeding season occupancy for Sierra Willow Flycatchers because of their high detection probability (Bombay et al. 2003b, Troyer and Blackwell 2004). In 2016 (the first year of the experiment) we surveyed experimental meadows once every 10-15 days (concurrent with visits to change batteries in broadcast units) between 1 June and 15 July, generally beginning as soon as snowmelt made meadows accessible. At control meadows where frequent visits to change batteries were not required, we conducted surveys twice. In 2017 we selected (mostly) new study meadows, and crew members attempted to visit each of them (both experimental and control sites) every 10-15 days as soon as meadows became accessible, to improve consistency in sampling effort between experimental and control meadows. We also surveyed all experimental and control meadows used in 2016 again at least twice in 2017, but we did not redeploy automated broadcast units at the 2016 experimental sites, except for the three control meadows we reused as experimental meadows in 2017.

Surveys began each morning within 10 minutes of sunrise and were concluded before 10:00, when Willow Flycatcher vocalizations begin to decline. We turned off broadcast units while active surveys took place. Surveyors conducted broadcast surveys at predetermined survey stations located $50 \mathrm{~m}$ apart throughout 
Table 1. Experimental (with conspecific broadcast) and control (without conspecific broadcast) meadows surveyed for Willow Flycatchers (Empidonax traillii) in 2016 or 2017.

\begin{tabular}{|c|c|c|c|c|c|c|c|c|}
\hline \multirow[t]{2}{*}{ Site Name } & \multirow[t]{2}{*}{ Site Type } & \multirow{2}{*}{$\begin{array}{c}\text { Broadcast } \\
\text { Start }\end{array}$} & \multicolumn{5}{|c|}{ Survey Dates } & \multirow{2}{*}{$\begin{array}{l}\% \text { of Visits with } \\
\text { WIFL } \\
\text { Detections }\end{array}$} \\
\hline & & & 1 & 2 & 3 & 4 & 5 & \\
\hline Carman Knuthson & Experimental & $5 / 25 / 16$ & $6 / 3 / 16$ & $6 / 13 / 16^{\dagger}$ & $6 / 22 / 16^{\dagger}$ & $7 / 1 / 16^{\dagger}$ & $7 / 8 / 16$ & 60 \\
\hline Cookhouse Meadow & Experimental & $5 / 15 / 16$ & $6 / 10 / 16$ & $6 / 14 / 16$ & $6 / 29 / 16$ & $7 / 6 / 17$ & $7 / 15 / 16$ & 0 \\
\hline Dangberg Camp & Experimental & $5 / 11 / 16$ & $6 / 10 / 16$ & $6 / 20 / 16$ & $6 / 30 / 16$ & $7 / 6 / 16$ & $7 / 15 / 16$ & 0 \\
\hline Indian Valley & Experimental & $6 / 18 / 16$ & $6 / 29 / 16^{\dagger}$ & $7 / 8 / 16^{\dagger}$ & $7 / 14 / 16^{\dagger}$ & & & 1 \\
\hline Last Chance Creek & Experimental & $5 / 25 / 16$ & $6 / 6 / 16$ & $6 / 16 / 16$ & $6 / 26 / 16$ & $7 / 6 / 16$ & $7 / 13 / 16$ & 0 \\
\hline Poco Red Clover & Experimental & $5 / 13 / 16$ & $6 / 8 / 16$ & $6 / 19 / 15$ & $6 / 29 / 16$ & $7 / 7 / 16$ & $7 / 14 / 16$ & 0 \\
\hline Red Lake Creek 1 & Experimental & $5 / 12 / 16$ & $6 / 10 / 16$ & $6 / 20 / 16$ & $6 / 30 / 16^{\dagger}$ & $7 / 7 / 17$ & $7 / 14 / 16$ & 20 \\
\hline Benwood Meadows N. & Control & NA & $6 / 7 / 16$ & $6 / 15 / 16$ & & & & 0 \\
\hline Benwood Meadows S. & Control & NA & $6 / 7 / 16$ & $6 / 15 / 16$ & & & & 0 \\
\hline Davies Creek & Control & NA & $6 / 2 / 16$ & $6 / 20 / 16$ & & & & 0 \\
\hline Fountain Place & Control & NA & $6 / 6 / 16$ & $6 / 15 / 16^{\dagger}$ & & & & 50 \\
\hline Last Chance Creek Confl. & Control & NA & $6 / 5 / 16$ & $6 / 16 / 16$ & $7 / 6 / 16$ & & & 0 \\
\hline Meiss Meadow & Control & NA & $6 / 21 / 16$ & $7 / 11 / 16$ & & & & 0 \\
\hline Saddle Meadow & Control & NA & $6 / 1 / 16$ & $6 / 17 / 16$ & & & & 0 \\
\hline Green Creek Central & Experimental & NA & $6 / 8 / 17$ & $6 / 17 / 17$ & $6 / 28 / 17$ & $7 / 2 / 17$ & $7 / 12 / 2017^{*}$ & 20 \\
\hline Last Chance Creek Confl. & Experimental & $5 / 19 / 17$ & $6 / 4 / 17$ & $6 / 16 / 17$ & $6 / 25 / 17$ & $7 / 4 / 17$ & $7 / 14 / 17$ & 0 \\
\hline Little Antelope Creek & Experimental & $5 / 19 / 17$ & $6 / 4 / 17$ & $6 / 16 / 17^{\dagger}$ & $6 / 25 / 17^{\dagger}$ & $7 / 4 / 17^{\dagger}$ & $7 / 14 / 17$ & 60 \\
\hline Lower Robinson Creek & Experimental & $5 / 17 / 17$ & $6 / 9 / 17$ & $6 / 18 / 17$ & $6 / 28 / 17$ & $7 / 3 / 17$ & $7 / 14 / 17$ & 0 \\
\hline Red Lake 1 & Experimental & $5 / 15 / 17$ & $6 / 15 / 17$ & $6 / 23 / 17$ & $7 / 3 / 17$ & $7 / 11 / 17$ & & 0 \\
\hline Red Lake Peak & Experimental & $5 / 30 / 17$ & $6 / 15 / 17$ & $6 / 24 / 17$ & $7 / 3 / 17$ & $7 / 11 / 17$ & & 0 \\
\hline Virginia Creek & Experimental & $5 / 17 / 17$ & $6 / 9 / 17$ & $6 / 18 / 17$ & $6 / 28 / 17$ & $7 / 4 / 17$ & $7 / 14 / 17$ & 0 \\
\hline Benwood Meadow N. & Control & NA & $6 / 4 / 17$ & $6 / 22 / 17$ & $7 / 7 / 17$ & & & 0 \\
\hline Benwood Meadow S. & Control & NA & $6 / 22 / 17$ & $7 / 7 / 17$ & & & & 0 \\
\hline Conway Ranch & Control & NA & $6 / 11 / 17^{\S}$ & $6 / 19 / 17$ & $7 / 4 / 17$ & $7 / 13 / 17$ & & 25 \\
\hline Conway Summit & Control & NA & $6 / 10 / 17$ & $6 / 19 / 17$ & $7 / 3 / 17$ & $7 / 15 / 17$ & & 0 \\
\hline Green Creek East & Control & NA & $6 / 8 / 17$ & $6 / 17 / 17$ & $6 / 28 / 17$ & $7 / 2 / 17$ & $7 / 12 / 17$ & 0 \\
\hline Green Creek West & Control & NA & $6 / 8 / 17$ & $6 / 17 / 17$ & $6 / 28 / 17$ & $7 / 2 / 17$ & $7 / 12 / 17$ & 0 \\
\hline Hungry Creek & Control & NA & $6 / 4 / 17$ & $6 / 17 / 17$ & $7 / 5 / 17$ & $7 / 15 / 17$ & & 0 \\
\hline Little Grizzly & Control & NA & $6 / 25 / 17$ & $7 / 5 / 17$ & $7 / 15 / 17$ & & & 0 \\
\hline Red Lake 2 & Control & NA & $6 / 15 / 17$ & $6 / 23 / 17$ & $7 / 3 / 17$ & $7 / 11 / 17$ & & 0 \\
\hline Saddle Meadow & Control & NA & $6 / 6 / 17$ & $6 / 20 / 17$ & & & & 0 \\
\hline Upper Buckeye Creek & Control & NA & $6 / 10 / 17$ & $6 / 20 / 17$ & $7 / 5 / 17$ & $7 / 15 / 17$ & & 0 \\
\hline Upper Willow Creek 4 & Control & NA & $6 / 6 / 17$ & $6 / 22 / 17$ & $7 / 1 / 17$ & $7 / 11 / 17$ & & 0 \\
\hline
\end{tabular}

all appropriate habitat within each meadow. Surveyors spent six minutes at each station, first passively listening for Willow Flycatchers and then playing territorial calls to elicit a response. Depending on meadow size, surveys included from 7 to 78 stations.

\section{Habitat data}

We collected data relating to three habitat variables that previous studies have indicated may influence Willow Flycatcher occupancy: meadow area, meadow wetness, and extent of deciduous riparian scrub cover (Bombay 1999, Bombay et al. 2003a, Mathewson et al. 2013). To calculate meadow size, we used satellite imagery in ArcMap to manually correct meadow boundaries delineated in the Sierra Nevada Multi-Source Meadow Polygons Compilation, v. 2.0 (UC Davis, Center for Watershed Sciences, and U.S. Forest Service 2017). We defined an individual meadow as a contiguous patch of herbaceous and woody riparian vegetation separated by at least $300 \mathrm{~m}$ from the nearest such patch. We used this $300 \mathrm{~m}$ threshold to define the boundaries of individual meadows because it is approximately twice the diameter of the maximum observed territory size for Willow Flycatchers in the Sierra Nevada (Prescott 1986, Sanders and Flett 1989, Timossi et al. 1995, Bombay et al. 2003b).

We used 2012 NAIP satellite imagery to estimate the percent of each meadow covered by riparian deciduous shrubs, as validated by ocular estimates of overall shrub cover made on-site by surveyors. To index overall meadow wetness, surveyors recorded the estimated percent cover of surface water within a $10-\mathrm{m}$ radius of each survey station every time they surveyed the meadow, and then we averaged those measurements for each meadow.

\section{Data analysis}

To initially assess whether the number of experimental meadows colonized differed significantly from control meadows, we used a Fisher's exact test of significance, which is designed to accommodate small sample sizes (Ward and Schlossberg 2004). Consistent with Bombay et al. (2003b), we considered a meadow to be colonized if we detected one or more Willow Flycatchers 
displaying territorial or nesting behavior (e.g., singing, territory defense, conspecific interactions, carrying nesting material, carrying food, or attending to a nest or young) between 15 June and 15 July or if an individual was detected during more than one survey visit between 15 May and 25 July. These criteria were designed to ensure that transient birds were not considered within our analysis.

We conducted two sets of candidate model analyses: one using a binomial dependent variable of colonization status (colonized or noncolonized) similar to that used in the Fisher exact test, and another using the proportion of individual survey visits during which Willow Flycatchers were detected in a given season. We used this second metric of Willow Flycatcher presence because, although detection probability is high for Willow Flycatchers (Green et al. 2003), the differences in sampling effort between experimental and control sites, especially 2016, has the potential to confound the study. By considering the proportion of survey visits with Willow Flycatcher detections, rather than whether a detection occurred at all, we place a greater weight on detections at sites where fewer surveys were conducted.

To determine which covariates, including the conspecific broadcast treatment, influenced the proportion of survey visits when we detected Willow Flycatchers, we created candidate generalized linear regression models that included four meadowlevel covariates: presence of conspecific broadcasts, meadow area, average percent water cover, and percent deciduous riparian vegetation cover, as well as interactions between all variables. We then ranked these models using Akaike's Information Criterion corrected for small sample size $\left(\mathrm{AIC}_{\mathrm{c}}\right.$; Burnham and Anderson 2002). We considered $\Delta \mathrm{AIC}_{\mathrm{c}} \leq 2$ to indicate competitive models. We also examined whether these same four covariates influenced colonization as a binomial factor by creating candidate logistic regression models and identifying the model best able to predict colonization using $\mathrm{AIC}_{\mathrm{c}}$. However, we did not include models that contained interaction effects between these variables because these more complex models were nonconvergent.

To ensure that our results were not biased by differences in habitat characteristics of the randomly assigned experimental and control meadows, we used multiple logistic regression to examine whether area, wetness, elevation, or vegetation cover differed significantly between control and experimental meadows.

\section{RESULTS}

Between 2016 and 2017 we surveyed a total of 33 meadows, 14 experimental and 19 control. Willow Flycatchers were seven times more likely to colonize experimental meadows than control meadows. We observed territorial Willow Flycatchers at 5 of 14 (35.7\%) experimental meadows and at 1 of $19(5.3 \%)$ control meadows (Table 1, Fig. 1 [Fisher exact $P=0.0616$ ]). Colonizations occurred across the latitudinal range of the study area, including both the northernmost and southernmost experimental meadows. In all cases, we observed detected birds singing or displaying other territorial or nesting behaviors (detailed below).

Of the five colonized experimental meadows, Willow Flycatchers were observed singing and defending a territory at four, and at three of those meadows Willow Flycatchers were observed during multiple visits (Table 1). At the remaining colonized experimental meadow, a Willow Flycatcher was observed carrying food, indicating the presence of young. We detected a single territorial Willow Flycatcher during one breeding-season visit to a control meadow (Table 1). In 2017, we detected an additional Willow Flycatcher, not included in the above totals, at a control meadow prior to the breeding season, but we did not encounter any Willow Flycatchers during subsequent surveys, indicating it was likely transient (Table 1). All repeated detections at a single meadow were centered within the same areas of the meadow and likely represent the same bird(s).

During the 2017 season we observed no Willow Flycatchers at any of the 14 meadows that were used as study meadows during the 2016 season. However, record snowfall during the winter of 2016/2017 caused the Fountain Place, Indian Valley, and Red Lake Creek meadows to remain partially or totally under snow until mid to late June, when Willow Flycatchers would typically initiate nesting (Sedgwick 2000, Mathewson et al. 2013). Additionally, meadows colonized by Willow Flycatchers in 2017 were among those where snow was absent earliest during the season because of being either at low elevation or at the southernmost portion of the study region. Across the two years of the study the average area $(\bar{x}=47.43 \mathrm{ha}, \mathrm{SE} \pm 39.18 \mathrm{ha}$, min $=3.0$ ha, $\max =146.7 \mathrm{ha})$, percent water cover $(\bar{x}=29.58, \mathrm{SE}$ $\pm 7.06, \min =0.68, \max =84.3)$, elevation $(\bar{x}=2058.5 \mathrm{~m}, \mathrm{SE}$ $\pm 91.63 \mathrm{~m}, \min =1511 \mathrm{~m}, \max =2419 \mathrm{~m})$, and percent riparian shrub cover $(\bar{x}=44.64, \mathrm{SE}= \pm 6.98, \min =5, \max =85)$ of experimental meadows did not differ significantly from the area $(\bar{x}=39.18$ ha, $\mathrm{SE} \pm 11.86 \mathrm{ha}, \min =3.0 \mathrm{ha}, \max =157.3 \mathrm{ha})$, percent water cover $(\bar{x}=32.42, \mathrm{SE} \pm 4.88, \min =3.5, \max =72.5)$, elevation $(\bar{x}=2213 \mathrm{~m} \mathrm{SE} \pm 64.8 \mathrm{~m}, \min =1677 \mathrm{~m}, \max =2585$ $\mathrm{m})$ or percent shrub cover $(\bar{x}=42.64, \mathrm{SE} \pm 5.14, \min =10$, $\max$ $=80$; Table 2) of control meadows, indicating that differences in colonization at experimental and control meadows were not due to differences in these habitat characteristics between treatment types.

Table 2. Regression model testing the relationship between treatment type and habitat characteristics within study meadows.

\begin{tabular}{lcccc}
\hline \hline Covariate & Estimate & Std. Error & $Z$ & $P$ \\
\hline Intercept & 3.0725 & 2.6133 & 1.176 & 0.240 \\
Area & -0.0063 & 0.0079 & 0.799 & 0.424 \\
Elevation & -0.0020 & 0.0013 & -1.525 & 0.127 \\
Water & -0.0039 & 0.0188 & -0.206 & 0.837 \\
Vegetation & 0.0169 & 0.0190 & 0.888 & 0.375 \\
\hline
\end{tabular}

The top supported model that predicted the percent of survey visits when we encountered Willow Flycatchers included the presence of conspecific broadcasts, meadow area, and the interactive effect of presence or absence of broadcasts and meadow area (Table 3$)$. The only other competitive model $(<2 \Delta$ $\mathrm{AIC}_{\mathrm{c}}$ ) included these variables in addition to deciduous riparian shrub cover (Table 3 ). Presence of broadcasts and meadow area alone were not significant predictors of Willow Flycatcher encounters ( $\beta_{\text {broadcast }}=-0.07,95 \% \mathrm{CI}=-0.24-0.1$ and $\beta_{\text {size }}=0.0003$, $95 \%$ CI $=-0.0012-0.0012$ ), but the interaction between these covariates was a significant predictor $\left(\beta_{\text {broadcast } \mathrm{x} \mathrm{size}}=0.0045,95 \%\right.$ $\mathrm{CI}=0.0018-0.0072)$. Percent of surveys with Willow Flycatcher 
Fig. 1. Locations of all meadows used as control (black) or experimental sites (white) during the 2016 and 2017 Willow Flycatcher (Empidonax traillii) breeding season in the Sierra Nevada, California. Stars indicate sites where Willow Flycatchers were detected displaying territorial or nesting behaviors between 15 June and 15 July. All 2016 study meadows shown were also resurveyed during the 2017 breeding season.
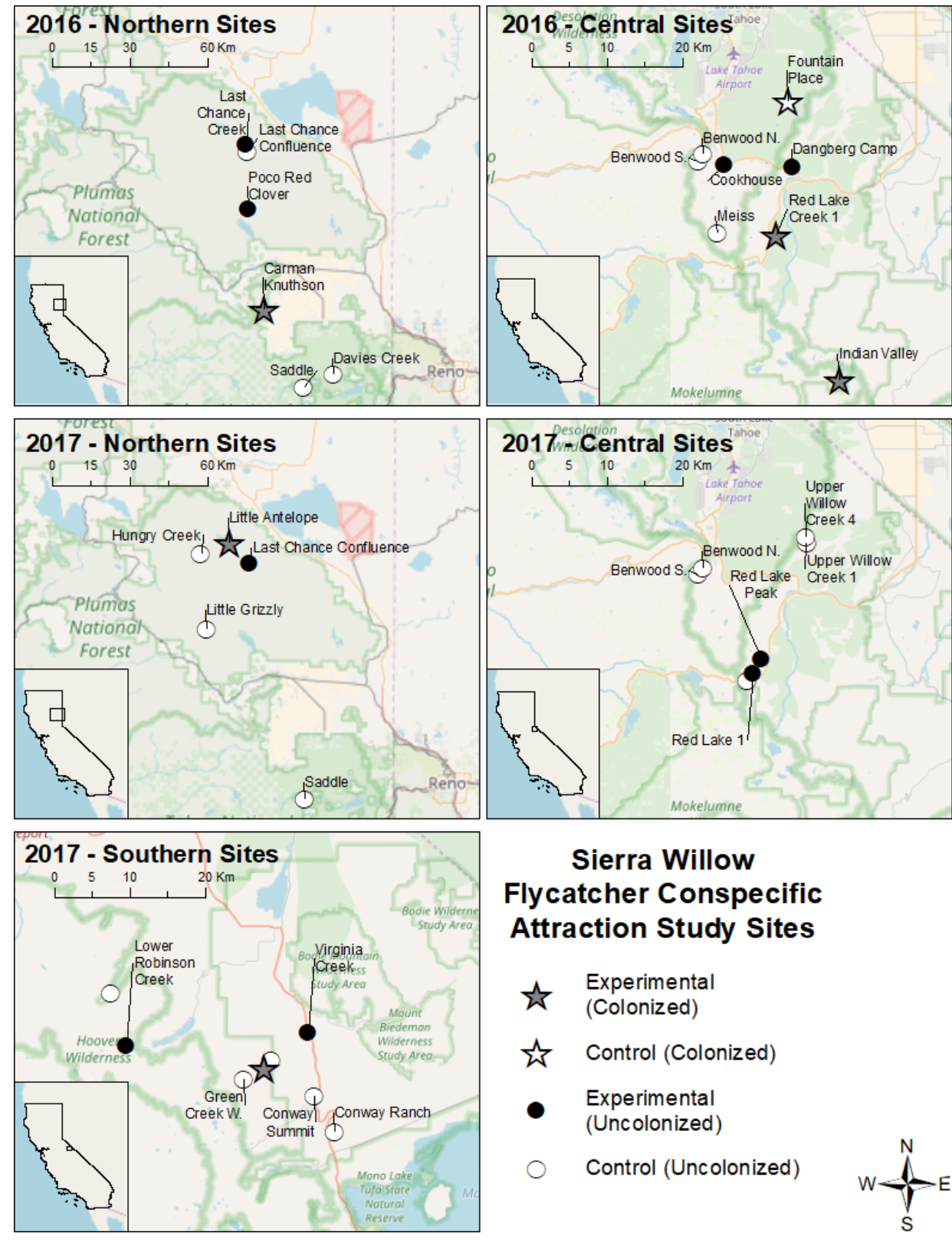

\section{Sierra Willow \\ Flycatcher Conspecific \\ Attraction Study Sites}

$$
\begin{aligned}
& \text { th } \begin{array}{l}
\text { Experimental } \\
\text { (Colonized) }
\end{array} \\
& \text { 解 Control (Colonized) } \\
& \text { - Experimental } \\
& \text { (Uncolonized) } \\
& \text { Control (Uncolonized) }
\end{aligned}
$$<smiles>NC(F)(F)S</smiles>

detections was positively related to the presence of broadcasts and increased with meadow area (Fig. 2).

The model that best predicted the overall colonization of a meadow included both the presence of conspecific broadcasts and meadow area (Table 4). Experimental meadows were more frequently colonized $\left(\beta_{\text {broadcast }}=2.62,95 \% \mathrm{CI}=0.4-6.03\right)$, and colonized experimental meadows were larger on average $(\bar{x}=$ 87.74 ha, $\mathrm{SE} \pm 19.58)$ than uncolonized meadows $(\bar{x}=39.17$ ha, $\mathrm{SE} \pm 11.86 ; \beta_{\text {size }}=0.02,95 \% \mathrm{CI}=0-0.05$; Fig. 3$)$. The top competitive models all included presence or absence of conspecific broadcasts, as well as meadow size and deciduous shrub cover (Table 4). 
Table 3. Top ranked logistic regression models $\left(<2 \Delta \mathrm{AIC}_{\mathrm{c}}\right)$ predicting percent of survey visits where Willow Flycatchers $($ Empidonax traillii) were detected.

\begin{tabular}{lcccc}
\hline \hline Model & Log-likelihood & df & AIC & Delta AIC $(\Delta)$ \\
\hline Broadcasts + Area + (Broadcasts*Area) & 11.868 & 5 & -12 & 0 \\
Broadcasts + Area + Vegetation + & 12.562 & 6 & -9.9 & 1.62 \\
(Broadcasts*Area) & & & & \\
\hline
\end{tabular}

Fig. 2. The relationship between meadow size and the percentage of survey visits where Willow Flycatchers (Empidonax traillii) were positively detected at any time during the breeding season, including one site where a nonterritorial Willow Flycatcher was detected once, prior to the 15 June cutoff we established for documenting colonization.

Experimental sites where conspecific broadcasts took place are represented by black circles and control sites without broadcasts are represented by white circles. Regression lines depict the relationship between meadow size and detection for experimental sites (in black) and control sites (in gray).

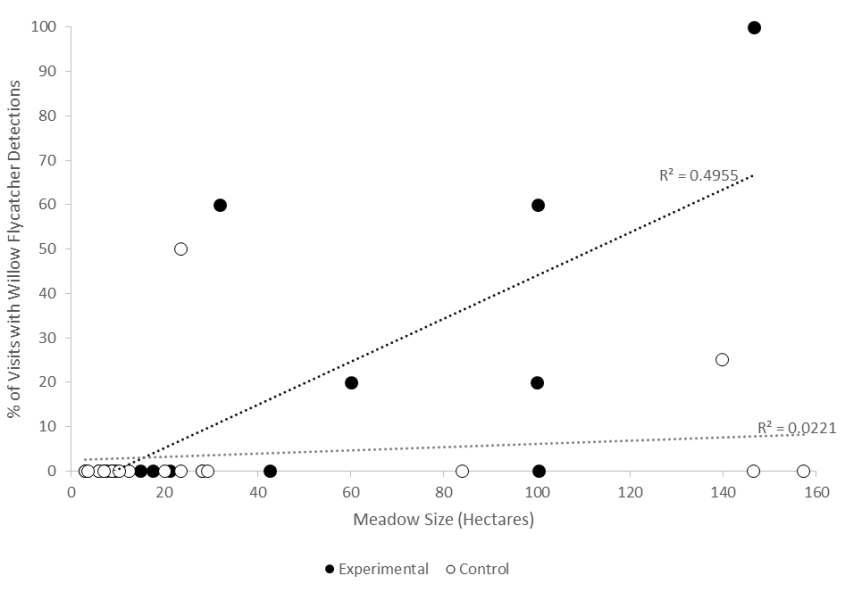

Fig. 3. Mean size ( \pm SE) of control and experimental meadows colonized (dark gray) and unoccupied (light gray) by Willow Flycatchers (Empidonax traillii) in the Sierra Nevada, California.

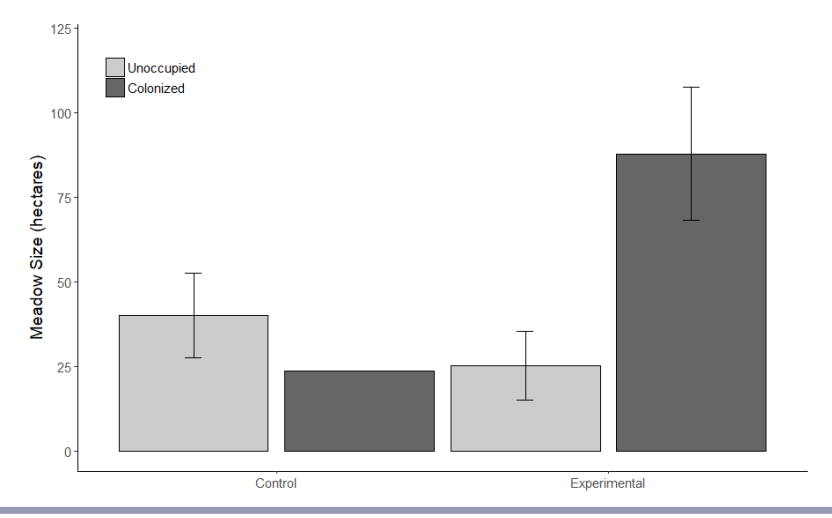

\section{DISCUSSION}

Providing social cues in the form of conspecific broadcasts increased the rate at which restored and improved meadow habitat in the Sierra Nevada was colonized by Willow Flycatchers by seven times. These results demonstrate that conspecific broadcasts, when used in combination with meadow restoration and improved management practices, is likely to be a valuable tool for helping restore Sierra Willow Flycatchers across their historic range. Conspecific broadcast may also be effective in helping to restore other declining populations such as the Southwestern Willow Flycatcher (Empidonax traillii extimus) or be effective as a means of restoring multiple declining meadow species simultaneously (DeJong et al. 2015).

This is the first study we know of to document how differences in habitat patch attributes affect the response to conspecific broadcasts in a songbird species (Ahlering et al. 2010, DeJong et al. 2015). The size of the meadow where broadcasts took place significantly affected Willow Flycatcher colonization. Conspecific broadcasts were successful only when used within a large area of restored meadow habitat. No experimental meadows smaller than 40 ha were colonized during our study, despite the small size of Willow Flycatcher territories and the fact that an area of less than 40 ha is capable of supporting numerous flycatcher pairs (Loffland et al. 2014). Meadow size is positively related to Willow Flycatcher productivity even at higher flycatcher densities, suggesting that larger meadows provide better habitat overall (Sedgwick 2004, Mathewson et al. 2013). Although Willow Flycatchers appear to use the perceived presence of conspecifics in territory selection, the presence of social cues alone is evidently not enough to attract prospecting Willow Flycatchers; characteristics of the meadows where conspecific broadcasts are deployed influence the efficacy of the broadcasts. In contrast, studies of the Least Flycatcher (Empidonax minimus), a more generalized upland relative, is reported to respond consistently to conspecific attraction irrespective of habitat patch size (Fletcher 2009).

Neither shrub cover nor average surface water cover significantly influenced Willow Flycatcher colonization. Perhaps Willow Flycatchers rely on social cues to infer the suitability of these characteristics, which makes sense considering that willows are often not fully leafed out and the duration of standing water persistence through the breeding season cannot be directly assessed during the settlement period. However, all the meadows included in this study met the basic requirements for breeding Willow Flycatchers. Rather than indicating that flycatchers did not assess these characteristics, our results may instead simply reflect that shrub cover and surface water did not differ enough among our study meadows to influence colonization probability. 
Table 4. Top ranked logistic regression models $\left(<2 \Delta \mathrm{AIC}_{\mathrm{c}}\right)$ predicting Willow Flycatcher (Empidonax traillii) colonization.

\begin{tabular}{|c|c|c|c|c|c|}
\hline Model & Log-likelihood & $\mathrm{df}$ & $\mathrm{AIC}_{c}$ & Delta $\mathrm{AIC}_{c}(\Delta \mathrm{c})$ & Akaike weight $\left(w_{i}\right)$ \\
\hline Broadcast + Area & -11.236 & 3 & 29.3 & 0 & 0.222 \\
\hline Broadcast + Vegetation & -11.622 & 3 & 30.1 & 0.77 & 0.151 \\
\hline Broadcast & -13.042 & 2 & 30.5 & 1.19 & 0.123 \\
\hline Broadcast + Area + Vegetation & -10.538 & 4 & 30.5 & 1.21 & 0.121 \\
\hline Broadcast + Vegetation + Water & -11.219 & 4 & 31.9 & 2.57 & 0.061 \\
\hline Broadcast + Area + Water & -11.236 & 4 & 31.9 & 2.6 & 0.06 \\
\hline $\begin{array}{l}\text { Broadcast + Area + Vegetation }+ \\
\text { Water }\end{array}$ & -10.039 & 5 & 32.3 & 3 & 0.049 \\
\hline
\end{tabular}

Although conspecific broadcasts improved the rate at which new colonists arrived at suitable habitat, their effectiveness in retaining new and productive populations into the future still requires investigation. We did not detect Willow Flycatchers at any of the sites colonized during the 2016 season again in 2017. However, the 2017 season had record high precipitation and snowpack in the Sierra Nevada, and conditions were relatively unfavorable for nesting Willow Flycatchers across much of our study area, as leafing out was delayed by several weeks and many meadows were covered in snow well past their usual median nest initiation date (Mathewson et al. 2013). In the most extreme instance, one of the meadows colonized in 2016 did not become accessible to the survey crew until after young would typically fledge (Bombay et al. 2003a, Mathewson et al. 2013).

We also did not actively assess nesting success of the Willow Flycatchers that colonized our meadows, and, indeed, few other studies have attempted to address breeding success in relation to conspecific broadcasts (Ahlering et al. 2010, Andrews et al. 2015, Grendelmeier et al. 2017). Attraction to conspecifics likely helps to improve survival by minimizing the time birds need to search for new territory and increasing opportunities for individuals to find mates (Fletcher 2006), but artificially provided conspecific broadcasts has not explicitly been shown to improve survival of reproductive success (Ahlering et al. 2010, Grendelmeier et al. 2017). Because most prospecting Willow Flycatchers seeking to establish new territories are second-year individuals and typically less productive than their older counterparts (Sedgwick 2004, Paxton et al. 2007), we would not necessarily expect to see high productivity in the short term from individuals attracted to a habitat by conspecific broadcasts.

Because knowledge gaps about the long-term efficacy of conspecific broadcasts as a restoration strategy remain, caution should be used when introducing conspecific broadcasts into unoccupied habitat. Care should be taken to ensure that Willow Flycatchers are not drawn into unproductive sink habitat that might siphon individuals away from otherwise productive source populations (Pulliam 1988). That Sierra Willow Flycatchers are less likely to colonize smaller meadows provides some assurance that flycatchers will not necessarily settle near conspecific broadcasts when meadow characteristics are unfavorable. However, with so few Willow Flycatchers breeding in California the loss of any breeding individuals to unproductive habitat should be avoided (Beatty 2014). Until knowledge gaps are filled, this technique should be used only where habitat is of sufficiently high quality to allow managers to be confident that flycatchers have the potential to be productive.
We recommend that further implementation of conspecific broadcasts be accompanied by monitoring efforts to help determine nesting success and multiyear persistence of new colonists, and to further refine methods for implementing broadcasts, e.g., the duration, placement, season and timing of broadcasts. If the potential negative impacts of conspecific attraction, i.e., attracting birds to sink habitat, are avoided, the technique could prove to be an important conservation tool and a way to help prevent continued declines and extirpations of Willow Flycatchers in the Sierra Nevada and elsewhere.

Responses to this article can be read online at: http://www.ace-eco.org/issues/responses.php/1216

\section{Acknowledgments:}

We thank N. Beliveau, C. Cumberworth, J. Jaeger, J. Jarz, F. Lane, D. Lipp, M. Martin, S. Polfer, S. Schick, M. Simon, and D. St George for field assistance, J. Wu for assistance building and programming broadcast units, and $S$. Peterson for comments on the manuscript. We thank two anonymous reviewers for providing comments to help improve this manuscript. We thank M. Easton, $R$. Nickerson, S. Zanetti, and others with the USDA Forest Service for facilitating field work and helping to identify survey sites. The California Department of Fish and Wildlife, National Fish and Wildlife Foundation and The Sierra Foothills Audubon Society provided funding for this study. IBP contribution number 591.

\section{LITERATURE CITED}

Ahlering, M. A., D. Arlt, M. G. Betts, R. J. Fletcher, Jr., J. J. Nocera, and M. P. Ward. 2010. Research needs and recommendations for the use of conspecific-attraction methods in the conservation of migratory songbirds. Condor 112:252-264. http://dx.doi.org/10.1525/cond.2010.090239

Andrews, J. E., J. D. Brawn, and M. P. Ward. 2015. When to use social cues: conspecific attraction at newly created grasslands. Condor 117:297-305. http://dx.doi.org/10.1650/CONDOR-14-172.1

Beatty, G. 2014. Southwestern Willow Flycatcher (Empidonax traillii extimus) 5-year review: summary and evaluation. U.S. Fish and Wildlife Service, Arizona Ecological Services, Phoenix, Arizona, USA. [online] URL: https://www.fws.gov/southwest/es/ Documents/R2ES/SouthwesternWillowFlycatcher_5YrReview_2014. pdf 
Bombay, H. L. 1999. Scale perspectives in habitat selection and reproductive success for Willow Flycatchers (Empidonax traillii) in the central Sierra Nevada, California. Thesis. California State University, Sacramento, California, USA.

Bombay, H. L., T. M. Benson, B. E. Valentine, and R. A. Stefani. 2003b. A Willow Flycatcher survey protocol for California. U.S., Forest Service, Pacific Southwest Region, Vallejo, California, USA.

Bombay, H. L., M. L. Morrison, and L. S. Hall. 2003a. Scale perspectives in habitat selection and animal performance for Willow Flycatchers (Empidonax traillii) in the central Sierra Nevada, California. Studies in Avian Biology 26:60-72.

Burnham, K. P., and D. R. Anderson. 2002. Model selection and multimodel inference: a practical information-theoretic approach. Springer Science and Business Media, New York, New York, USA. http://dx.doi.org/10.1007/b97636

Campos, B. R., R. D. Burnett, H. L. Loffland, and R. B. Siegel. 2014. Evaluating meadow restoration in the Sierra Nevada using birds and their habitat associations. Report to the National Fish and Wildlife Foundation, Point Blue Conservation Science, Petaluma, California, USA.

DeJong, L. N., S. D. Cowell, T. N. N. Nguyen, and D. S. Proppe. 2015. Attracting songbirds with conspecific playback: a community approach. Behavioral Ecology 26:1379-1388. http:// dx.doi.org/10.1093/beheco/arv094

Fletcher, Jr., R. J. 2006. Emergent properties of conspecific attraction in fragmented landscapes. American Naturalist 168:207-219. http://dx.doi.org/10.1086/505764

Fletcher, Jr.,, R. J. 2009. Does attraction to conspecific explain the patch-size effect? Oikos 118:1139-1147. http://dx.doi. org/10.1111/j.1600-0706.2009.17342.x

Green, G. A., H. L. Bombay, and M. L. Morrison. 2003. Conservation assessment of the Willow Flycatcher in the Sierra Nevada. U.S. Forest Service, Pacific Southwest Region, Vallejo, California, USA. [online] URL: https://www.sierraforestlegacy. org/Resources/Conservation/SierraNevadaWildlife/WillowFlycatcher/ WF-Green03.pdf

Grendelmeier, A., R. Arlettaz, J. Olano-Marin, and G. Pasinelli. 2017. Experimentally provided conspecific cues boost bird territory density but not breeding performance. Behavioral Ecology 28:174-185. http://dx.doi.org/10.1093/beheco/arw144

Grinnell, J., and A. H. Miller. 1945. The distribution of the birds of California. Nature 156(34). http://dx.doi.org/10.1038/156034b0

Hahn, B. A., and E. D. Silverman. 2006. Social cues facilitate habitat selection: American redstarts establish breeding territories in response to song. Biology Letters 2:337-340. http:// dx.doi.org/10.1098/rsbl.2006.0472

Hammersmark, C. T., M. C. Rains, and J. F. Mount. 2008. Quantifying the hydrological effects of stream restoration in a montane meadow, Northern California, USA. River Research and Applications 24:1085-1095. http://dx.doi.org/10.1002/rra.1077

Harris, J. H., S. D. Sanders, and M. A. Flett. 1986. The status and distribution of Willow Flycatchers in California. California Department of Fish and Game, Sacramento, California, USA.
Harris, J. H., S. D. Sanders, and M. A. Flett. 1987. Willow Flycatcher surveys in the Sierra Nevada. Western Birds 18:27-36.

Kus, B. E., S. L. Howell, and D. A. Wood. 2017. Female-biased sex ratio, polygyny, and persistence in the endangered southwestern Willow Flycatcher (Empidonax traillii extimus). Condor 119:17-25. http://dx.doi.org/10.1650/CONDOR-16-119.1

Loffland, H. L., C. Stermer, R. D. Burnett, B. R. Campos, and T. Mark. 2014. Assessing Willow Flycatcher population size and distribution to inform meadow restoration priorities in the Sierra Nevada and Southern Cascades. Point Reyes Station, California, USA.

Lovell, S. F., and M. R. Lein. 2004. Neighbor-stranger discrimination by song in a suboscine bird, the Alder Flycatcher, Empidonax alnorum. Behavioral Ecology 15:799-804. http://dx. doi.org/10.1093/beheco/arh082

Mathewson, H. A., H. L. Loffland, and M. L. Morrison. 2011. Demographic analysis for Willow Flycatcher monitoring in the central Sierra Nevada, 1997-2010: final report. In partial fulfillment of Cost Share Agreement 06-CR-11052007-160 between Texas A\&M University and U.S. Forest Service region 5. Department of Wildlife and Fisheries Sciences, Texas A\&M University, College Station, Texas, USA.

Mathewson, H. A., M. L. Morrison, H. L. Loffland, and P. F. Brussard. 2013. Ecology of Willow Flycatchers (Empidonax traillii) in the Sierra Nevada, California: effects of meadow characteristics and weather on demographics. Ornithological Monographs 75:1-32. http://dx.doi.org/10.1525/om.2013.75.1.1

Muller, K. L., J. A. Stamps, V. V Krishnan, and N. H. Willits. 1997. The effects of conspecific attraction and habitat quality on habitat selection in territorial birds (Troglodytes aedon). American Naturalist 150:650-661. http://dx.doi.org/10.1086/286087

Oles, K. M., D. A. Weixelman, D. F. Lile, K. W. Tate, L. K. Snell, and L. M. Roche. 2017. Riparian meadow response to modern conservation grazing management. Environmental Management 60:383-395. http://dx.doi.org/10.1007/s00267-017-0897-1

Paxton, E. H., S. L. Durst, M. K. Sogge, T. J. Koronkiewicz, and K. L. Paxton. 2017. Survivorship across the annual cycle of a migratory passerine, the Willow Flycatcher. Journal of Avian Biology 48:1126-1131. http://dx.doi.org/10.1111/jav.01371

Paxton, E. H., M. K. Sogge, S. L. Durst, T. C. Theimer, and J. R. Hatten. 2007. The ecology of the Southwestern Willow Flycatcher in Central Arizona: a 10-year synthesis report. Open File Report 2007-1381. U.S. Geological Survey, Washington, D.C., USA.

Pope, K. L., D. S. Montoya, J. N. Brownlee, J. Dierks, and T. E. Lisle. 2015. Habitat conditions of montane meadows associated with restored and unrestored stream channels of California. Ecological Restoration 33:61-73. http://dx.doi.org/10.3368/ er.33.1.61

Prescott, D. R. C. 1986. Polygyny in the Willow Flycatcher. Condor 88:385-386. http://dx.doi.org/10.2307/1368891

Pulliam, H. R. 1988. Sources, sinks, and population regulation. American Naturalist 132:652-661. http://dx.doi.org/10.1086/284880

Sanders, S. D., and M. A. Flett. 1989. Ecology of a Sierra Nevada population of Willow Flycatchers. Western Birds 18:37-42. 
Sedgwick, J. A. 2000. Willow Flycatcher (Empidonax traillii), version 2.0. In A. Poole and F. B. Gill, editors. The birds of North America. Cornell Lab of Ornithology, Ithaca, New York, USA. https://doi.org/10.2173/bna.533

Sedgwick, J. A. 2004. Site fidelity, territory fidelity, and natal philopatry in Willow Flycatchers (Empidonax Traillii). Auk 121:1103-1121. http://dx.doi.org/10.1642/0004-8038(2004)121[1103: SFTFAN]2.0.CO;2

Sedgwick, J. A., and F. L. Knopf. 1992. Describing Willow Flycatcher habitats: scale perspectives and gender differences. Condor 94:720-733. http://dx.doi.org/10.2307/1369257

Siegel, R. B., R. L. Wilkerson, and D. F. DeSante. 2008. Extirpation of the Willow Flycatcher from Yosemite National Park. Western Birds 39:8-21.

Small, A. 1994. California birds: their status and distribution. Ibis, Vista, California, USA.

Timossi, I. C., E. L. Woodard, and R. H. Barrett. 1995. Habitat suitability models for use with Arc/Info: Willow Flycatcher. CWHR Technical Report No. 26. California Department of Fish and Game, CWHR Program, Sacramento, California, USA.

Troyer, J., and J. Blackwell. 2004. Sierra Nevada Forest Plan amendment, final supplemental environmental impact statement. U.S. Forest Service, Pacific Southwest Region, Vallejo, California, USA.

University of California Davis (UC Davis), Center for Watershed Sciences, and U.S. Forest Service. 2017. Sierra Nevada MultiSource Meadow Polygons Compilation (v2.0). U.S. Forest Service, Regional Office, Vallejo, California, USA.

Valentine, B. E., T. A. Roberts, S. P. Borland, and A. P. Woodman. 1988. Livestock management and productivity of Willow Flycatchers in the central Sierra Nevada. Transactions Of The Western Section Of The Wildlife Society 24:105-114.

Vormwald, L. M., M. L. Morrison, H. A. Mathewson, M. C. Cocimano, and B. A. Collier. 2011. Survival and movements of fledgling Willow and Dusky flycatchers. Condor 113:834-842. http://dx.doi.org/10.1525/cond.2011.110009

Walkinshaw, L. H. 1966. Biology of Traill's Flycatcher. Wilson Bulletin 78:31-46.

Ward, M. P., and S. Schlossberg. 2004. Conspecific attraction and the conservation of territorial songbirds. Conservation Biology 18:519-525. http://dx.doi.org/10.1111/j.1523-1739.2004.00494.x 